This is a self-archived version of an original article. This version may differ from the original in pagination and typographic details.

Author(s): Johansson, E.; Böckerman, P.; Lundqvist, A.

Title: Self-reported health versus biomarkers : does unemployment lead to worse health?

Year: 2020

Version: Accepted version (Final draft)

Copyright: (c) 2019 The Royal Society for Public Health

Rights: $C C$ BY-NC-ND 4.0

Rights url: https://creativecommons.org/licenses/by-nc-nd/4.0/

Please cite the original version:

Johansson, E., Böckerman, P., \& Lundqvist, A. (2020). Self-reported health versus biomarkers : does unemployment lead to worse health?. Public Health, 179, 127-134.

https://doi.org/10.1016/j.puhe.2019.10.005 
Self-reported health versus biomarkers: Does unemployment really lead to worse health?

Associate Professor Edvard Johansson, Ph.D. (corresponding author)

Åbo Akademi University, Turku, Finland

Address: Tuomiokirkontori 320500 Turku, Finland

E-mail: edvard.johansson@abo.fi

Professor Petri Böckerman, Ph.D.

University of Jyväskylä (School of Business and Economics), Jyväskylä, Finland

Labour Institute for Economic Research and IZA Institute of Labor Economics

Senior Researcher Annamari Lundqvist, Ph.D.

National Institute for Welfare and Health, Helsinki, Finland

* Financial support

Böckerman acknowledges financial support from the Academy of Finland Strategic Research Council project Work, Inequality and Public Policy (number 293120). 


\title{
Self-reported health versus biomarkers: Does unemployment really lead to worse health?
}

\begin{abstract}
This paper examines the effect of unemployment on health using both subjective and biometric information on health status. We compare the results of regressions of unemployment on selfreported health to regressions where health is measured by using biomarkers (hypertension, the level of blood glucose and C-reactive protein). Using the panel structure of our data we control for selection bias into unemployment by accounting for health before the exposure to unemployment. We observe a striking pattern. Using self-reported health as the outcome variable, we find that there is a link from unemployment to worse health. By contrast, we are unable to find the same link using biometric information on health. In conclusion, our results point to a substantial discrepancy between self-reported health and health measured by biomarkers.
\end{abstract}

Keywords: unemployment, self-assessed health, biomarkers 


\section{Introduction}

A sizeable empirical literature documents that adverse labour market outcomes affect individuals' health negatively (Roelfs et al. 2011; Wanberg, 2012). In many research settings, the health outcome used is self-reported health, as self-assessed health is less costly to obtain and readily available in well-known panel data sets such as British Household Panel Survey (Contoyannis et al. 2004). However, regarding the connection between labour market status and health, research shows that results obtained by using health measurements performed by health professionals differ systematically from individuals' self-reported health (Lindeboom and Kerkhofs, 2009; Christensen and Kallestrup-Lamb, 2012; Johnston et al. 2009). One reason for this pattern is what is called justification bias, i.e. individuals consciously or subconsciously, misreport their self-reported health compared what their "objective" health is.

This paper re-examines the relationship between unemployment and (bad) health. Our contribution is based on the use of both subjective and objective biometric measures of individuals' health in a panel data setting. We first study using self-reported health whether there is a negative link between unemployment and health. We then use the standard biometric measures of health, i.e. hypertension, the level of blood glucose and C-reactive protein that are prominent biomarkers related to prevalent chronic health conditions in industrialized countries. The earlier empirical evidence on the link between unemployment and biomarkers is sparse. Hughes et al. (2015) use cross-sectional UK data to examine the relationship between inflammatory biomarkers and unemployment and Michaud et al. (2016) analyze the effects of job loss on biomarkers in the US context. 


\section{Methods}

\subsection{Study design and sample}

The data that we use in this study comes from the panel based on the Health in Finland 2000 and the Health in Finland 2011 data sets. The Health 2000 in Finland Survey comprehensively represents the Finnish population aged 30 years and over. The methods and base results of the 2000 survey have been previously described in detail (Heistaro, 2008), and they are available at http://www.terveys2000.fi/. Briefly, the survey had a two-stage, stratified cluster sampling design, with double sampling of people over 80 years of age (Aromaa, 2004). Data were collected between August 2000 and July 2001. Of the original sample of 8,028 people, 93\% participated in at least one part of the study.

In 2011, the data for a follow-up to this survey, the Health in Finland 2011 were collected. 72.9 percent of the sample of persons aged 30 and over $(n=7964)$ took part in at least one of the phases of the data collection, while 58.6 percent took part in the health examination. The National Institute for Health and Welfare in Finland, in collaboration with a broad-based network of experts, co-ordinated the planning and implementation of the survey (Koskinen et al., 2012). Thus, the follow-up sample that we are using in this study consists of individuals aged 41 or over in 2011. The same type of stratified cluster sampling that was used in the 2000 survey was also applied in the 2011 survey. Because the sample used in the analysis consists of individuals employed in 2000 that also participate in the 2011 survey, it is possible that some of the very unhealthy individuals will be left out of the analysis due to the sample restriction. Consequently, the results do not apply to individuals in the very low end of the health distribution. 


\subsection{Measures}

We use two main explanatory variables. The first one is current unemployment and the second is the number of months of unemployment the individual has experienced during the last five years. The unemployment measures are based on interviews, which for this question was done in the same way in both waves of the data. The unemployment measures that we use in the analysis refer specifically to individuals in the labour force and who are available for work but are currently without it (the standard ILO definition of unemployment).

As already indicated, we use four different dependent variables in this paper. The first one is self-reported health, which was gathered in health interviews both in 2000 and 2011.

Respondents were asked to answer the standard question: "How is your current health?" and the five answer categories were: 1: "very good", 2: "good", 3: "average", 4: "rather bad" and 5: "bad". The second dependent variable is hypertension. In the Health 2000 and Health 2011 data sets, systolic and diastolic was measured twice by trained health professionals, with a standard mercury manometer (Riester Diplomat Presameter Desk Set), and from the mean of those measurements we have constructed a dichotomous variable taking the value 1 if the person has hypertension and 0 otherwise. A person is considered to have hypertension if the systolic pressure is $140 \mathrm{mmHg}$ or higher or if the diastolic blood pressure is $90 \mathrm{mmHg}$ or higher (Chobanian et al. 2003). Furthermore, individuals that were treated with drugs for high blood pressure were also categorized as having high blood pressure. The reason for using hypertension as a biomarker in this context is that hypertension is the most prevalent chronic health condition in Western countries and is a major risk factor for cardiovascular diseases (Lackland and Weber, 2015). The third dependent variable is C-reactive protein, measured by 
immunoturbidimetric method. C-reactive protein is a general marker for inflammation and infection in the body (Koenig et al. 1999). The level of C-reactive protein has been linked in previous research to the perceived level of chronic stress (Shivpuri et al. 2012) that can be triggered by unemployment. As measurements of C-reactive protein display a highly skewed distribution, we used a log transformation in all regressions. The fourth dependent variable is serum glucose, measured by enzymatic hexokinase. An elevated blood glucose level is an early indicator of diabetes, and is also related to the elevated risk of cardiovascular diseases (Singh et al. 2013). As this measure can be sensitive to the time of fasting before measurement, individuals that had a time of fast of less than four hours before measurement were excluded in that regression. A total of 41 or $2.05 \%$ of the cases were removed owing to this.

Furthermore, health is obviously also dependent on a host of other variables. In accordance with previous literature, we add as control variables age, a gender dummy, education indicators, variables measuring the household composition as well as several variables measuring risky health behaviors of the individuals, such as alcohol consumption, diet, smoking, and physical exercise. We also add regional control variables to account for large permanent differences in health outcomes in Finland.

Regarding age it is likely that the effects on health are non-linear. Therefore, we construct age dummies that correspond to five-year intervals. Education is also measured by dummy variables for the levels of education, instead of a linear variable measuring years of education. Household composition is measured by a dummy indicating whether an individual is married or cohabiting, as well as by a variable measuring household size. 
Alcohol consumption is measured by two variables. The first one measures how many times in a week an individual drinks alcohol and the second how many drinks of alcohol an individual drinks when drinking. Smoking is measured by the number of cigarettes per week an individual smokes. Diet is measured by two variables, the number of times an individual consumes fruit, and the number of times per week an individual consumes vegetables. Finally, exercise is measured by how many times per week an individual exercises at least 30 minutes.

\subsection{Statistical methods}

We study why there are health differences between individuals, and how unemployment is linked to those differences. To capture as much of the causal effect of unemployment on health status as possible, we first include in our sample only those persons who were employed in 2000. Some of these individuals either experienced unemployment during the period 20062011 (when we are able to measure unemployment) or were unemployed in 2011 when the follow-up data were collected. We then start out with a simple regression model with the measures of health as the dependent variable, and individuals' experiences of unemployment as the main independent variables. However, earlier research has shown that there is a selection bias into unemployment, so that individuals with worse health are more likely to experience unemployment. Therefore, as an additional independent variable, we add the individuals' health status in 2000 to the models. Thus, in a sense we are estimating health change models, where health in 2011 is dependent on health in 2000. As a starting point, we use OLS (Ordinary Least Squares) techniques in all regressions. However, we also supplement, for the case when the dependent variable is self-reported health, those regressions with ordered probit 
models. Importantly, we account for the two-stage stratification of the data in all regressions. The calibrated weights alleviate the potential bias related to attrition.

\section{Results}

Table 1 provides descriptive statistics for our sample. Clearly, given the data that we use, the individuals in it are quite old. Other than that, the descriptive statistics clearly conveys the representativeness of the data for the Finnish population in 2011.5 percent of the individuals are currently unemployed, which is a bit lower that the national average at that time, but the difference is a consequence of the focus on older people, and also because we have selected only individuals that were employed in 2000. Individuals in the sample smoke on average 5.56 cigarettes per week, drink alcohol 1.26 times per week and drink 2.96 drinks on average per alcohol drinking occasion. It is noticeable that individuals are on average moderately overweight, as the average BMI is slightly less than 27.

Table 1 also reports the descriptive statistics broken down by employment status. We find that most health measures are much better for those who are employed. In addition, there are systematic differences between employed and unemployed persons in the data in terms of background characteristics. For example, employed persons have higher education level compared to unemployed.

In Table 2, we first present the estimates when the dependent variable is (bad) self-reported health. In the first column, we only have age and the male dummy together with our 
unemployment variables as independent variables, and the result is very much as expected.

Both current unemployment and months of unemployment are linked to worse health, measured as (bad) self-reported health. In the second column, we add our education, risky health behaviors, and family composition variables. Again, the result comes out very much as expected with physical exercise associated with better self-reported health and overweight worsening it. The education variables also come out very much as expected, as individuals that are more educated have better self-reported health. Our unemployment variables are attenuated to some extent but are still statistically significant. In the third column we add individual selfreported health in 2000. This is highly significant, implying that those who had lower selfreported health in 2000 also have lower self-reported health in 2011. Thus, health is a durable good to a large extent, and within-person correlation of health over time is high. Interestingly, this attenuates the coefficients to some extent, albeit somewhat more regarding the variables other than the unemployment variables. Finally, in column 4, we add regional dummies to the regression model. This does not alter the results very much, although regional health differences in Finland are evidently very large (Kilpeläinen, 2016). The quantitative magnitude of the estimates regarding the link between unemployment and health is considerable. For example, the estimates show that being currently unemployed increases the probability of reporting bad health by 24 percent (column 4 of Table 2). In appendix Table A1, we rerun the regressions presented in Table 2, but this time using an ordered probit model. The results are not qualitatively different compared to those of Table 2.

In Table 3, we report the results when health is measured by biomarkers. In the table, the specification is the same as the specification used in the rightmost specification in Table 2, i.e. with all controls included. As can be seen from the table, the results look markedly different compared to the results in Table 2 . In column 2 of Table 3, when health is measured by 
hypertension, neither the variable measuring months of unemployment nor current unemployment is significant. Furthermore, the lagged dependent variable is highly significant. Thus, there is a substantial selection effect such that those who already have hypertension in 2000 are much more likely to have hypertension in 2011 . The other control variables offer expected results, such as that a high BMI increases the incidence of hypertension, whereas eating fruit often as well as physical exercising often decreases the incidence of hypertension. Intriguingly, we also find that smoking is associated with lower incidence of hypertension. $A$ priori one would envisage that smoking would increase the probability of hypertension. However, this result may be due to underlying correlation with other explanatory variables that is unaccounted for in the current empirical setup. As it is not the specific topic of this paper, we will not probe further into that question. In appendix Tables A2 and A3, we present results of regressions where the dependent variables are the diastolic and systolic blood pressure of the individual, measured in 2011. Regarding the coefficients for the unemployment variables, we see that there are no qualitative differences compared to Table 3.

In column 2 of Table 3, we use C-reactive protein as our dependent variable. Again, we observe that our unemployment variables are not significant. And again, regarding the lagged outcome variable, we can see that it is highly significant, indicating that those who had elevated level of C-reactive protein in 2000 also had it in 2011. Regarding the control variables, we observe that drinking and smoking is not favorable for health measured in this way, and neither is having a high BMI. Physical exercising is associated with lower levels of C-reactive protein. 
Finally, in the rightmost column of Table 3, the results where glucose is used as the dependent variable are presented. The unemployment variables show some unexpected results here, with more months of unemployment actually being associated with lower levels of glucose.

Although unexpected, it does not alter our general message in this paper, quite the opposite. Again, regarding the control variables, having a high BMI is associated with higher glucose, as is how many times a week the individual drinks alcohol. The lagged dependent variable is again highly significant. Related to our findings, Hughes and Kumari (2017) have observed that unemployed people are not necessarily heavier than employed people.

As robustness checks, we present in appendix Table A4 results of regressions where we have rerun the regressions presented in Table 3, but without the lifestyle and health behaviour variables. Again, the results remain unchanged. Finally, Table A5 confirms that there is a statistically significant link between self-reported health and all three biometric measures of health that we are using in the models. This is in line with previous research that has established a link between self-reported health and objective health measures (e.g Idler \& Benyamini, 1997).

\section{Discussion}

Using self-reported health as the outcome variable, we find that there is a well-established link from unemployment to bad health. By contrast, current unemployment and months of unemployment during the last five are not linked to individuals' biometric health measures. We control for selection bias into unemployment by using the follow-up (panel) structure of our 
data. On that account, we find that there is a substantial selection based on health status into unemployment, such that individuals with worse health are much more likely to experience unemployment (Böckerman and Ilmakunnas, 2009).

One potential explanation for the results obtained may be justification bias. Another one could be that unemployment is an unpleasant experience but mainly affects mental health, and that mental health is uncorrelated with the biomarkers we are using in this study. However, we judge that to be unlikely as there is quite a bit of evidence suggesting that mental health problems correlate with abnormal values in biomarkers (Liukkonen et al. 2006; Licht et al. 2009; Valkanova et al. 2013).

Furthermore, it is possible that we are not picking up health in a meaningful manner by the biomarkers we are using. However, as elevated levels in any of the biomarkers we are using cover a substantial part of the total burden of disease in society, we also judge this a somewhat far-fetched explanation. Also, our results show that subjective and objective health measures are correlated. However, further research may be needed on this point, which would be the correct biomarkers that would actually pick up the link from unemployment to bad health, if it is not the ones evaluated in this paper?

Another possibility is that the unemployment measures used in the empirical specifications are not sufficient in measuring unemployment experience accurately enough, although we find it unlikely that this is the case. Unemployment experience during the last five years captures considerable burden stemming from weak labour market attachment, and we find it unlikely that the results would be biased owing to the fact that we are not using for instance ten years of employment history. On balance, our results point to a substantial discrepancy between selfreported health and health measured by standard biomarkers. 
Two other issues are relevant for the interpretation of our results. First, our sample includes only those persons who were employed in 2000 . There is potential health selection regarding participation to the labour force and being employed in 2000. Those who had worst health in 2000 were most likely out of the labour force (cf. Beatty et al. 2000). This may lead to conservative estimates. Second, it is possible that the country-context is relevant for the interpretation of the results. The impact of unemployment on physical health may be lower in Finland than in some other country contexts due to differences in policies, e.g. welfare provision for unemployed persons. For example, the coverage of earnings-related unemployment benefits among unemployed is higher in Finland than in many other industrialized countries (OECD, 2018).

Our results indicate that using exclusively self-reported health may lead to biased results in research on important relationships in social sciences. Research therefore has a potential to improve by increasingly using more objective and more precise measures of health status instead of subjective evaluations and outcomes (Blanchflower et al. 2008).

\section{Conclusion}

In this paper we studied the between unemployment and health. We compared the results of regressions of unemployment on self-reported health to regressions where health is measured by biomarkers. Using panel data we accounted for selection into unemployment by accounting for health before exposure to unemployment. We find interesting differences when comparing the effect of unemployment with the effect of unemployment on biomarkers. For self-reported 
health, we observe that there is a link from unemployment to worse health, but we are unable to detect the same effect using the biomarkers. We conclude that the allocation of health care resources using solely subjective measures may lead to non-optimal designs. 


\section{References}

Blanchflower D, Christakis N, Oswald A. (2011). An introduction to the structure of biomarker equations. Working paper.

Beatty C., Fothergill S., Macmillan R. (2000). A theory of employment, unemployment and sickness. Reg Stud 34:617-630.

Böckerman P, Ilmakunnas P. (2009). Unemployment and self-assessed health: Evidence from panel data. Health Econ 18:161-179.

Chobanian AV, Bakris GL, Black HR, et al. (2003). The seventh report of the joint national committee on prevention, detection, evaluation, and treatment of high blood pressure: The JNC 7 report. JAMA 289:2560-2571.

Chobanian AV, Bakris GL, Black HR, et al. (2003). The seventh report of the joint national committee on prevention, detection, evaluation, and treatment of high blood pressure: The JNC 7 report. JAMA 289:2560-2571.

Christensen BJ, Kallestrup-Lamb M. (2012). The impact of health changes on labor supply: Evidence from merged data on individual objective medical diagnosis codes and early retirement behaviour. Health Econ 21:56-100.

Contoyannis P, Jones AM, Rice N. (2004). The dynamics of health in the British Household Panel Survey. Journal of Applied Econometrics 19:473-503.

Heistaro S. (2008). Methodology report: Health 2000 Survey. Helsinki: National Public Health Institute.

Hughes A, McMunn A, Bartley M, Kumari M. (2015). Elevated inflammatory biomarkers during unemployment: Modification by age and country in the UK. J Epidemiol Community Health 69:673-679. 
Hughes A, Kumari M. (2017). Unemployment, underweight, and obesity: Findings from Understanding Society (UKHLS). Prev Med 97:19-25.

Johnston DW, Propper C, Shields, MA. (2009). Comparing subjective and objective measures of health: Evidence from hypertension for the income/health gradient. J Health Econ 28:540552.

Idler, EL, Benyamini, Y. (1997). Self-rated health and mortality: a review of twenty-seven community studies. J Health Social Behav: 21-37.

Lindeboom M, Kerkhofs M. (2009). Health and work of the elderly: Subjective health measures, reporting errors and endogeneity in the relationship between health and work. J Appl Econ 24:1024-1046.

Licht CM, de Geus EJ, Seldenrijk A, et al. (2009). Depression is associated with decreased blood pressure, but antidepressant use increases the risk for hypertension. Hypertension 53:631-638.

Liukkonen T, Silvennoinen-Kassinen S, Jokelainen J, et al. 2006. The association between Creactive protein levels and depression: Results from the Northern Finland 1966 birth cohort study. Biol Psychiatry 60:825-830.

Lundqvist A, Mäki-Opas T (2016). (Eds). Health 2011 Surveys - Methods. National Institute for Health and Welfare, Report 08/2016. Helsinki.

Kilpeläinen K. (2016). Finnish experiences of health monitoring: Local, regional, and national data sources for policy evaluation Glob Health Action 9:1-9.

Michaud PC, Crimmins, EM, Hurd MD. (2016). The effect of job loss on health: Evidence from biomarkers. Labour Econ 41:194-203.

OECD (2018). OECD Employment Outlook 2018. OECD, Paris. 
Roelfs DJ, Shor E, Davidson KW, Schwartz JE. (2011). Losing life and livelihood: A systematic review and meta-analysis of unemployment and all-cause mortality. Soc Sci Med $72: 840-854$.

Shivpuri S, Gallo LC, Crouse JR, Allison, MA. (2012). The association between chronic stress type and C-reactive protein in the multi-ethnic study of atherosclerosis: does gender make a difference? J Behav Med 35:74-85.

Singh GM, Danaei G, Farzadfar F, et al. (2013). The age-specific quantitative effects of metabolic risk factors on cardiovascular diseases and diabetes: A pooled analysis. PloS One 8(7):e65174.

Valkanova V, Ebmeier KP, Allan CL. (2013). CRP, IL-6 and depression: A systematic review and meta-analysis of longitudinal studies. J Affect Disord 150:736-744.

Wanberg CR. (2012). The individual experience of unemployment. Annu Rev of Psychol 63:369-396. 


\begin{tabular}{|c|c|c|c|c|c|c|}
\hline \multirow[b]{2}{*}{ Variable } & \multicolumn{2}{|c|}{ Whole sample } & \multicolumn{2}{|c|}{ Always employed } & \multicolumn{2}{|c|}{ Any unemployment } \\
\hline & Mean & Std.dev. & Mean & Std.dev & Mean & Std.dev \\
\hline Months of unemployment & 1.15 & 5.20 & $\overline{0}$ & $\overline{0}$ & 10.76 & 14.35 \\
\hline Currently unemployed & 0.06 & 0.23 & 0 & 0 & 0.26 & 0.44 \\
\hline Self-reported health 2000 & 1.65 & 0.79 & 1.63 & 0.77 & 1.79 & 0.84 \\
\hline Self-reported health 2011 & 1.68 & 0.82 & 1.65 & 0.79 & 1.91 & 0.97 \\
\hline Hypertension 2000 & 0.29 & & 0.29 & & 0.34 & \\
\hline Hypertension 2011 & 0.49 & & 0.48 & & 0.56 & \\
\hline Log of C-reactive protein $2000(\mathrm{mg} / \mathrm{l})$ & -1.29 & 2.45 & -1.29 & 2.44 & -1.19 & 2.47 \\
\hline Log of C-reactive protein $2011(\mathrm{mg} / \mathrm{l})$ & 0.08 & 1.06 & 0.05 & 1.03 & 0.11 & 1.14 \\
\hline Log of Glucose $2000(\mathrm{mmol} / \mathrm{l})$ & 1.66 & 0.12 & 1.65 & 0.12 & 1.65 & 0.11 \\
\hline Log of Glucose $2011(\mathrm{mmol} / \mathrm{l})$ & 1.66 & 0.14 & 1.65 & 0.14 & 1.66 & 0.12 \\
\hline Male & 0.49 & & 0.49 & & 0.54 & \\
\hline Age $40-44$ & 0.23 & & 0.23 & & 0.17 & \\
\hline Age 45-49 & 0.25 & & 0.24 & & 0.22 & \\
\hline Age 50-54 & 0.23 & & 0.23 & & 0.18 & \\
\hline Age 55-59 & 0.22 & & 0.20 & & 0.26 & \\
\hline Age 60-99 & 0.07 & & 0.07 & & 0.15 & \\
\hline No. times eating veg. / week & 4.91 & 2.12 & 4.94 & 2.12 & 4.59 & 2.12 \\
\hline No. times eating fruit / week & 4.06 & 2.53 & 4.10 & 2.51 & 3.72 & 2.60 \\
\hline No. times drinking alc. / week & 1.04 & 1.15 & 1.03 & 1.13 & 1.02 & 1.18 \\
\hline Alc. drinks / times drinking & 2.44 & 2.36 & 2.42 & 2.31 & 2.57 & 2.69 \\
\hline Times exercise /week & 2.40 & 2.06 & 2.38 & 2.02 & 2.34 & 2.13 \\
\hline Family size & 2.60 & 1.28 & 2.64 & 1.27 & 2.24 & 1.12 \\
\hline Married or cohabiting & 0.78 & & 0.80 & & 0.70 & \\
\hline Divorced & 0.11 & & 0.10 & & 0.11 & \\
\hline Number of cigarettes / week & 4.76 & 8.03 & 4.43 & 7.82 & 6.15 & 8.80 \\
\hline BMI & 26.92 & 4.65 & 26.98 & 4.63 & 27.04 & 4.86 \\
\hline Primary education & 0.02 & & 0.01 & & 0.03 & \\
\hline Lower secondary education & 0.06 & & 0.04 & & 0.09 & \\
\hline Upper secondary education & 0.06 & & 0.05 & & 0.07 & \\
\hline Post-secondary non-tertiary education & 0.38 & & 0.36 & & 0.45 & \\
\hline Bachelor or equivalent education & 0.33 & & 0.34 & & 0.24 & \\
\hline Master or equivalent education & 0.13 & & 0.13 & & 0.07 & \\
\hline Doctoral or equivalent education & 0.03 & & 0.03 & & 0.01 & \\
\hline Hospital region: Helsinki & 0.33 & & 0.33 & & 0.34 & \\
\hline Hospital region: Turku & 0.14 & & 0.14 & & 0.11 & \\
\hline Hospital region: Tampere & 0.22 & & 0.22 & & 0.24 & \\
\hline Hospital region: Kuopio & 0.16 & & 0.16 & & 0.15 & \\
\hline Hospital region: Oulu & 0.13 & & 0.13 & & 0.15 & \\
\hline
\end{tabular}

Notes: The table values represent the mean (or proportion) and standard deviation. 
Table 2: The effect of unemployment on bad self-reported health

\begin{tabular}{|c|c|c|c|c|}
\hline Months of unemployment & $\begin{array}{l}0.013 * * * \\
(0.004)\end{array}$ & $\begin{array}{l}0.009 * * \\
(0.004)\end{array}$ & $\begin{array}{l}0.008 * * \\
(0.003)\end{array}$ & $\begin{array}{l}0.008^{* * *} \\
(0.003)\end{array}$ \\
\hline Currently unemployed & $\begin{array}{l}0.306^{* * *} \\
(0.091)\end{array}$ & $\begin{array}{l}0.248 * * * \\
(0.085)\end{array}$ & $\begin{array}{l}0.238 * * * \\
(0.081)\end{array}$ & $\begin{array}{l}0.241 * * * \\
(0.081)\end{array}$ \\
\hline Male & $\begin{array}{l}0.030 \\
(0.039)\end{array}$ & $\begin{array}{l}-0.038 \\
(0.040)\end{array}$ & $\begin{array}{l}-0.044 \\
(0.039)\end{array}$ & $\begin{array}{l}-0.044 \\
(0.039)\end{array}$ \\
\hline Age $45-50$ years & $\begin{array}{l}0.117 * * \\
(0.050)\end{array}$ & $\begin{array}{l}0.103 * * \\
(0.047)\end{array}$ & $\begin{array}{l}0.079 * \\
(0.047)\end{array}$ & $\begin{array}{l}0.080 * \\
(0.047)\end{array}$ \\
\hline Age $50-55$ years & $\begin{array}{l}0.237 * * * \\
(0.059)\end{array}$ & $\begin{array}{l}0.155^{* * * *} \\
(0.060)\end{array}$ & $\begin{array}{l}0.104 * \\
(0.057)\end{array}$ & $\begin{array}{l}0.106 * \\
(0.057)\end{array}$ \\
\hline Age 55-60 years & $\begin{array}{l}0.245^{* * *} \\
(0.049)\end{array}$ & $\begin{array}{l}0.163 * * * \\
(0.056)\end{array}$ & $\begin{array}{l}0.084 \\
(0.054)\end{array}$ & $\begin{array}{l}0.087 \\
(0.055)\end{array}$ \\
\hline Age over 60 years & $\begin{array}{l}0.126 \\
(0.081)\end{array}$ & $\begin{array}{l}0.046 \\
(0.084)\end{array}$ & $\begin{array}{l}-0.029 \\
(0.079)\end{array}$ & $\begin{array}{l}-0.033 \\
(0.079)\end{array}$ \\
\hline No. times eating veg. / week & & $\begin{array}{l}0.007 \\
(0.010)\end{array}$ & $\begin{array}{l}0.004 \\
(0.009)\end{array}$ & $\begin{array}{l}0.003 \\
(0.009)\end{array}$ \\
\hline No. times eating fruit / week & & $\begin{array}{l}-0.009 \\
(0.010)\end{array}$ & $\begin{array}{l}-0.006 \\
(0.009)\end{array}$ & $\begin{array}{l}-0.006 \\
(0.009)\end{array}$ \\
\hline No. times drinking alc. / week & & $\begin{array}{l}-0.015 \\
(0.017)\end{array}$ & $\begin{array}{l}-0.019 \\
(0.016)\end{array}$ & $\begin{array}{l}-0.020 \\
(0.016)\end{array}$ \\
\hline Alc. drinks / times drinking & & $\begin{array}{l}0.010 \\
(0.010)\end{array}$ & $\begin{array}{l}0.007 \\
(0.009)\end{array}$ & $\begin{array}{l}0.006 \\
(0.009)\end{array}$ \\
\hline Times exercise /week & & $\begin{array}{l}-0.080^{* * * *} \\
(0.010)\end{array}$ & $\begin{array}{l}-0.067 * * * \\
(0.010)\end{array}$ & $\begin{array}{l}-0.067 * * * \\
(0.010)\end{array}$ \\
\hline Family size & & $\begin{array}{l}-0.040 * * \\
(0.017)\end{array}$ & $\begin{array}{l}-0.035^{* *} \\
(0.016)\end{array}$ & $\begin{array}{l}-0.035^{* *} \\
(0.016)\end{array}$ \\
\hline Married or cohabiting & & $\begin{array}{l}-0.095 \\
(0.075)\end{array}$ & $\begin{array}{l}-0.045 \\
(0.066)\end{array}$ & $\begin{array}{l}-0.042 \\
(0.066)\end{array}$ \\
\hline Divorced & & $\begin{array}{l}-0.022 \\
(0.096)\end{array}$ & $\begin{array}{l}0.041 \\
(0.092)\end{array}$ & $\begin{array}{l}0.041 \\
(0.092)\end{array}$ \\
\hline Number of cigarettes / week & & $\begin{array}{l}0.003 \\
(0.003)\end{array}$ & $\begin{array}{l}0.002 \\
(0.002)\end{array}$ & $\begin{array}{l}0.002 \\
(0.002)\end{array}$ \\
\hline $\mathrm{BMI}\left(\mathrm{kg} / \mathrm{m}^{2}\right)$ & & $\begin{array}{l}0.028 * * * \\
(0.004)\end{array}$ & $\begin{array}{l}0.021 * * * \\
(0.004)\end{array}$ & $\begin{array}{l}0.021 * * * \\
(0.004)\end{array}$ \\
\hline Upper secondary education & & $\begin{array}{l}-0.095 \\
(0.095)\end{array}$ & $\begin{array}{l}-0.106 \\
(0.091)\end{array}$ & $\begin{array}{l}-0.109 \\
(0.091)\end{array}$ \\
\hline Post-secondary non-tertiary education & & $\begin{array}{l}-0.081 \\
(0.075)\end{array}$ & $\begin{array}{l}-0.076 \\
(0.070)\end{array}$ & $\begin{array}{l}-0.079 \\
(0.070)\end{array}$ \\
\hline Bachelor or equivalent level & & $\begin{array}{l}-0.201 * * * \\
(0.073)\end{array}$ & $\begin{array}{l}-0.179 * * * \\
(0.066)\end{array}$ & $\begin{array}{l}-0.182 * * * \\
(0.067)\end{array}$ \\
\hline Master or equivalent level & & $\begin{array}{l}-0.197 * * \\
(0.083)\end{array}$ & $\begin{array}{l}-0.160 * * \\
(0.079)\end{array}$ & $\begin{array}{l}-0.164 * * \\
(0.079)\end{array}$ \\
\hline $\begin{array}{l}\text { Doctoral or equivalent level } \\
\text { (Bad) self-reported health } 2000\end{array}$ & & $\begin{array}{l}-0.286^{* *} \\
(0.142)\end{array}$ & $\begin{array}{l}-0.198 \\
(0.140) \\
0.302 * * * \\
(0.028)\end{array}$ & $\begin{array}{l}-0.201 \\
(0.140) \\
0.302 * * * \\
(0.028)\end{array}$ \\
\hline Constant & $\begin{array}{l}1.501 * * * \\
(0.040)\end{array}$ & $\begin{array}{l}1.325^{* * *} \\
(0.159) \\
\end{array}$ & $\begin{array}{l}0.959 * * * \\
(0.148) \\
\end{array}$ & $\begin{array}{l}0.977 * * * \\
(0.147) \\
\end{array}$ \\
\hline $\begin{array}{l}\text { R-squared } \\
\mathrm{N}\end{array}$ & $\begin{array}{l}0.033 \\
1994\end{array}$ & $\begin{array}{l}0.136 \\
1991\end{array}$ & $\begin{array}{l}0.214 \\
1989\end{array}$ & $\begin{array}{l}0.215 \\
1989\end{array}$ \\
\hline
\end{tabular}

Note: The dependent variable is an indicator for having bad self-reported health.

The reference category for the age dummies is being 41-44 years old in 2000.

The reference category for the Male dummy is female.

The reference category for the age dummies is $41-44$ years old. The reference category for the married or cohabiting dummy is not being married or cohabiting. The reference category for the divorced dummy is not divorced. Statistical significance: $* \mathrm{p}<0.1, * * \mathrm{p}<0.05, * * * \mathrm{p}<0.01$ 
Table 3: The effect of unemployment on biomarkers

\begin{tabular}{|c|c|c|c|}
\hline & Hypertension & C-reactive protein & Glucose \\
\hline Months of unemployment & $\begin{array}{l}-0.000 \\
(0.002)\end{array}$ & $\begin{array}{l}-0.001 \\
(0.005)\end{array}$ & $\begin{array}{l}-0.001 * * \\
(0.000)\end{array}$ \\
\hline Currently unemployed & $\begin{array}{l}0.017 \\
(0.047)\end{array}$ & $\begin{array}{l}0.058 \\
(0.106)\end{array}$ & $\begin{array}{l}0.018 \\
(0.016)\end{array}$ \\
\hline Male & $\begin{array}{l}0.070 * * * \\
(0.020)\end{array}$ & $\begin{array}{l}-0.189 * * * \\
(0.046)\end{array}$ & $\begin{array}{l}0.021 * * \\
(0.009)\end{array}$ \\
\hline Age $45-50$ years & $\begin{array}{l}0.059 * * \\
(0.026)\end{array}$ & $\begin{array}{l}0.035 \\
(0.069)\end{array}$ & $\begin{array}{l}0.008 \\
(0.008)\end{array}$ \\
\hline Age $50-55$ years & $\begin{array}{l}0.082 * * * \\
(0.029)\end{array}$ & $\begin{array}{l}0.038 \\
(0.081)\end{array}$ & $\begin{array}{l}0.020 * * \\
(0.009)\end{array}$ \\
\hline Age 55-60 years & $\begin{array}{l}0.094 * * * \\
(0.030)\end{array}$ & $\begin{array}{l}0.143^{*} \\
(0.082)\end{array}$ & $\begin{array}{l}0.023 * * \\
(0.012)\end{array}$ \\
\hline Age over 60 years & $\begin{array}{l}0.105^{* *} \\
(0.048)\end{array}$ & $\begin{array}{l}0.166 \\
(0.105)\end{array}$ & $\begin{array}{l}0.036^{* * *} \\
(0.014)\end{array}$ \\
\hline No. times eating veg. / week & $\begin{array}{l}-0.002 \\
(0.005)\end{array}$ & $\begin{array}{l}0.014 \\
(0.013)\end{array}$ & $\begin{array}{l}-0.000 \\
(0.002)\end{array}$ \\
\hline No. times eating fruit / week & $\begin{array}{l}-0.040 \text { *** } \\
(0.005)\end{array}$ & $\begin{array}{l}-0.022 \\
(0.014)\end{array}$ & $\begin{array}{l}-0.001 \\
(0.002)\end{array}$ \\
\hline No. times drinking alc. / week & $\begin{array}{l}-0.019^{*} \\
(0.010)\end{array}$ & $\begin{array}{l}-0.007 \\
(0.019)\end{array}$ & $\begin{array}{l}0.007 * * \\
(0.003)\end{array}$ \\
\hline Alc. drinks / times drinking & $\begin{array}{l}-0.008^{*} \\
(0.005)\end{array}$ & $\begin{array}{l}0.018^{*} \\
(0.010)\end{array}$ & $\begin{array}{l}0.001 \\
(0.001)\end{array}$ \\
\hline Times exercise /week & $\begin{array}{l}-0.030 * * * \\
(0.006)\end{array}$ & $\begin{array}{l}-0.033 * * * \\
(0.013)\end{array}$ & $\begin{array}{l}-0.000 \\
(0.002)\end{array}$ \\
\hline Family size & $\begin{array}{l}0.001 \\
(0.010)\end{array}$ & $\begin{array}{l}-0.046^{* *} \\
(0.022)\end{array}$ & $\begin{array}{l}-0.003 \\
(0.003)\end{array}$ \\
\hline Married or cohabiting & $\begin{array}{l}-0.017 \\
(0.034)\end{array}$ & $\begin{array}{l}0.211 * * * \\
(0.077)\end{array}$ & $\begin{array}{l}-0.007 \\
(0.013)\end{array}$ \\
\hline Divorced & $\begin{array}{l}-0.025 \\
(0.040)\end{array}$ & $\begin{array}{l}0.097 \\
(0.092)\end{array}$ & $\begin{array}{l}-0.016 \\
(0.014)\end{array}$ \\
\hline Number of cigarettes / week & $\begin{array}{l}-0.002 * \\
(0.001)\end{array}$ & $\begin{array}{l}0.012 * * * \\
(0.003)\end{array}$ & $\begin{array}{l}-0.000 \\
(0.000)\end{array}$ \\
\hline BMI $\left(\mathrm{kg} / \mathrm{m}^{2}\right)$ & $\begin{array}{l}0.011 * * * \\
(0.002)\end{array}$ & $\begin{array}{l}0.086^{* * * *} \\
(0.005)\end{array}$ & $\begin{array}{l}0.004 * * * \\
(0.001)\end{array}$ \\
\hline Upper secondary education & $\begin{array}{l}-0.042 \\
(0.053)\end{array}$ & $\begin{array}{l}0.046 \\
(0.129)\end{array}$ & $\begin{array}{l}-0.006 \\
(0.026)\end{array}$ \\
\hline Post-secondary non-tertiary education & $\begin{array}{l}-0.006 \\
(0.044)\end{array}$ & $\begin{array}{l}0.050 \\
(0.104)\end{array}$ & $\begin{array}{l}-0.033^{*} \\
(0.018)\end{array}$ \\
\hline Bachelor or equivalent level & $\begin{array}{l}0.004 \\
(0.044)\end{array}$ & $\begin{array}{l}0.022 \\
(0.099)\end{array}$ & $\begin{array}{l}-0.044 * * \\
(0.018)\end{array}$ \\
\hline Master or equivalent level & $\begin{array}{l}-0.077 \\
(0.053)\end{array}$ & $\begin{array}{l}0.047 \\
(0.112)\end{array}$ & $\begin{array}{l}-0.050 * * \\
(0.020)\end{array}$ \\
\hline Doctoral or equivalent level & $\begin{array}{l}-0.044 \\
(0.065) \\
\end{array}$ & $\begin{array}{l}-0.103 \\
(0.170) \\
\end{array}$ & $\begin{array}{l}-0.051^{* *} \\
(0.021)\end{array}$ \\
\hline
\end{tabular}

(table continues on next page) 
Table 3 (continued): The effect of unemployment on biomarkers

Hypertension $\quad$ C-reactive protein

Glucose

(Bad) self-reported health 2000

Hypertension 2000

$0.287 * * *$

(0.021)

Log of C-reactive protein 2000 (mg/l)

$0.114 * * *$

Log of Glucose 2000 (mmol/l)

(0.011)

Constant

$0.326 * * *$

(0.082)

R-squared

0.260

$\mathrm{N}$

1993

Note: The dependent variables are biomarkers.

Included in regressions but not reported are five regional dummies.

The reference category for the age dummies is being 41-44 years old in 2000.

The reference category for the Male dummy is female.

The reference category for the age dummies is 41-44 years old. The reference category for the married or cohabiting dummy is not being married or cohabiting. The reference category for the divorced dummy is not divorced

The reference category for the educational dummies is lower secondary education or less.

Statistical significance: $* \mathrm{p}<0.1, * * \mathrm{p}<0.05, * * * \mathrm{p}<0.01$ 
Table A1: The effect of unemployment on bad self-reported health.

\begin{tabular}{|c|c|c|c|c|}
\hline Months of unemployment & $\begin{array}{l}0.016^{* * * *} \\
(0.005)\end{array}$ & $\begin{array}{l}0.011 * * \\
(0.005)\end{array}$ & $\begin{array}{l}0.009 * * \\
(0.004)\end{array}$ & $\begin{array}{l}0.009 * * \\
(0.004)\end{array}$ \\
\hline Currently unemployed & $\begin{array}{l}0.375^{* * * *} \\
(0.110)\end{array}$ & $\begin{array}{l}0.310 * * * \\
(0.109)\end{array}$ & $\begin{array}{l}0.319 * * * \\
(0.110)\end{array}$ & $\begin{array}{l}0.322 * * * \\
(0.109)\end{array}$ \\
\hline Male & $\begin{array}{l}0.040 \\
(0.054)\end{array}$ & $\begin{array}{l}-0.060 \\
(0.061)\end{array}$ & $\begin{array}{l}-0.078 \\
(0.062)\end{array}$ & $\begin{array}{l}-0.078 \\
(0.062)\end{array}$ \\
\hline Age $45-50$ years & $\begin{array}{l}0.038 \\
(0.068)\end{array}$ & $\begin{array}{l}0.074 \\
(0.067)\end{array}$ & $\begin{array}{l}0.076 \\
(0.069)\end{array}$ & $\begin{array}{l}0.075 \\
(0.069)\end{array}$ \\
\hline Age $50-55$ years & $\begin{array}{l}0.204 * * * \\
(0.066)\end{array}$ & $\begin{array}{l}0.137 * * \\
(0.068)\end{array}$ & $\begin{array}{l}0.119^{*} \\
(0.069)\end{array}$ & $\begin{array}{l}0.119^{*} \\
(0.069)\end{array}$ \\
\hline Age 55-60 years & $\begin{array}{l}0.240 * * * \\
(0.060)\end{array}$ & $\begin{array}{l}0.191 * * * \\
(0.065)\end{array}$ & $\begin{array}{l}0.148 * * \\
(0.070)\end{array}$ & $\begin{array}{l}0.151 * * \\
(0.071)\end{array}$ \\
\hline Age over 60 years & $\begin{array}{l}0.051 \\
(0.097)\end{array}$ & $\begin{array}{l}-0.021 \\
(0.101)\end{array}$ & $\begin{array}{l}-0.097 \\
(0.098)\end{array}$ & $\begin{array}{l}-0.101 \\
(0.097)\end{array}$ \\
\hline No. times eating veg. / week & & $\begin{array}{l}0.010 \\
(0.014)\end{array}$ & $\begin{array}{l}0.006 \\
(0.014)\end{array}$ & $\begin{array}{l}0.005 \\
(0.014)\end{array}$ \\
\hline No. times eating fruit / week & & $\begin{array}{l}-0.011 \\
(0.014)\end{array}$ & $\begin{array}{l}-0.009 \\
(0.014)\end{array}$ & $\begin{array}{l}-0.009 \\
(0.014)\end{array}$ \\
\hline No. times drinking alc. / week & & $\begin{array}{l}-0.027 \\
(0.025)\end{array}$ & $\begin{array}{l}-0.032 \\
(0.026)\end{array}$ & $\begin{array}{l}-0.033 \\
(0.026)\end{array}$ \\
\hline Alc. drinks / times drinking & & $\begin{array}{l}0.013 \\
(0.013)\end{array}$ & $\begin{array}{l}0.010 \\
(0.014)\end{array}$ & $\begin{array}{l}0.009 \\
(0.014)\end{array}$ \\
\hline Times exercise /week & & $\begin{array}{l}-0.124 * * * \\
(0.016)\end{array}$ & $\begin{array}{l}-0.112 * * * \\
(0.016)\end{array}$ & $\begin{array}{l}-0.111 * * * \\
(0.016)\end{array}$ \\
\hline Family size & & $\begin{array}{l}-0.070 \text { *** } \\
(0.025)\end{array}$ & $\begin{array}{l}-0.056 * * \\
(0.025)\end{array}$ & $\begin{array}{l}-0.055^{* *} \\
(0.025)\end{array}$ \\
\hline Married or cohabiting & & $\begin{array}{l}-0.112 \\
(0.099)\end{array}$ & $\begin{array}{l}-0.058 \\
(0.095)\end{array}$ & $\begin{array}{l}-0.056 \\
(0.094)\end{array}$ \\
\hline Divorced & & $\begin{array}{l}-0.025 \\
(0.126)\end{array}$ & $\begin{array}{l}0.068 \\
(0.129)\end{array}$ & $\begin{array}{l}0.067 \\
(0.129)\end{array}$ \\
\hline Number of cigarettes / week & & $\begin{array}{l}0.005 \\
(0.003)\end{array}$ & $\begin{array}{l}0.004 \\
(0.004)\end{array}$ & $\begin{array}{l}0.005 \\
(0.004)\end{array}$ \\
\hline $\operatorname{BMI}\left(\mathrm{kg} / \mathrm{m}^{2}\right)$ & & $\begin{array}{l}0.041 * * * \\
(0.006)\end{array}$ & $\begin{array}{l}0.033 * * * \\
(0.006)\end{array}$ & $\begin{array}{l}0.033 * * * \\
(0.005)\end{array}$ \\
\hline Upper secondary education & & $\begin{array}{l}-0.124 \\
(0.126)\end{array}$ & $\begin{array}{l}-0.138 \\
(0.130)\end{array}$ & $\begin{array}{l}-0.140 \\
(0.129)\end{array}$ \\
\hline Post-secondary non-tertiary education & & $\begin{array}{l}-0.119 \\
(0.097)\end{array}$ & $\begin{array}{l}-0.102 \\
(0.095)\end{array}$ & $\begin{array}{l}-0.105 \\
(0.096)\end{array}$ \\
\hline Bachelor or equivalent level & & $\begin{array}{l}-0.308^{* * * *} \\
(0.097)\end{array}$ & $\begin{array}{l}-0.275^{* * * *} \\
(0.093)\end{array}$ & $\begin{array}{l}-0.277 * * * \\
(0.094)\end{array}$ \\
\hline Master or equivalent level & & $\begin{array}{l}-0.327 * * * \\
(0.117)\end{array}$ & $\begin{array}{l}-0.269^{* *} \\
(0.121)\end{array}$ & $\begin{array}{l}-0.270^{* *} \\
(0.121)\end{array}$ \\
\hline $\begin{array}{l}\text { Doctoral or equivalent level } \\
\text { (Bad) self-reported health } 2000\end{array}$ & & $\begin{array}{l}-0.506 * * \\
(0.229)\end{array}$ & $\begin{array}{l}-0.376 \\
(0.243) \\
0.448 * * * \\
(0.040)\end{array}$ & $\begin{array}{l}-0.375 \\
(0.243) \\
0.448^{* * *} \\
(0.039)\end{array}$ \\
\hline
\end{tabular}

(table continues on next page) 
Table A1: (continued): The effect of unemployment on bad self-reported health

\begin{tabular}{|c|c|c|c|c|}
\hline $\begin{array}{l}\text { cut1 } \\
\text { Constant }\end{array}$ & $\begin{array}{l}0.203 * * * \\
(0.059)\end{array}$ & $\begin{array}{l}0.482 * * \\
(0.212)\end{array}$ & $\begin{array}{l}1.087 * * * \\
(0.214)\end{array}$ & $\begin{array}{l}1.077 * * * \\
(0.215)\end{array}$ \\
\hline cut2 & & & & \\
\hline Constant & $\begin{array}{l}1.204 * * * \\
(0.064)\end{array}$ & $\begin{array}{l}1.564 * * * \\
(0.216)\end{array}$ & $\begin{array}{l}2.240 * * * \\
(0.219)\end{array}$ & $\begin{array}{l}2.231 * * * \\
(0.219)\end{array}$ \\
\hline cut3 & & & & \\
\hline Constant & $\begin{array}{l}2.136^{* * * *} \\
(0.079)\end{array}$ & $\begin{array}{l}2.560 * * * \\
(0.233)\end{array}$ & $\begin{array}{l}3.292 * * * \\
(0.233)\end{array}$ & $\begin{array}{l}3.284 * * * \\
(0.234)\end{array}$ \\
\hline cut4 & & & & \\
\hline Constant & $\begin{array}{l}2.841 * * * \\
(0.146)\end{array}$ & $\begin{array}{l}3.288 * * * \\
(0.277)\end{array}$ & $\begin{array}{l}4.051 * * * \\
(0.269)\end{array}$ & $\begin{array}{l}4.042 * * * \\
(0.271)\end{array}$ \\
\hline $\begin{array}{l}\text { R-squared } \\
\mathrm{N}\end{array}$ & 1994 & 1991 & 1989 & 1989 \\
\hline
\end{tabular}

Note: The dependent variable is an indicator for having bad self-reported health.

The model is estimated using ordered probit regression.

The reference category for the age dummies is being 41-44 years old in 2000 .

The reference category for the Male dummy is female.

The reference category for the age dummies is 41-44 years old. The reference category for the married or cohabiting dummy is not being married or cohabiting. The reference category for the divorced dummy is not divorced

The reference category for the educational dummies is lower secondary education or less.

Statistical significance: $* \mathrm{p}<0.1, * * \mathrm{p}<0.05, * * * \mathrm{p}<0.01$ 
Table A2: The effect of unemployment on diastolic blood pressure

\begin{tabular}{|c|c|c|c|c|}
\hline Months of unemployment & $\begin{array}{l}-0.045 \\
(0.059)\end{array}$ & $\begin{array}{l}-0.030 \\
(0.061)\end{array}$ & $\begin{array}{l}-0.036 \\
(0.060)\end{array}$ & $\begin{array}{l}-0.052 \\
(0.061)\end{array}$ \\
\hline \multirow[t]{2}{*}{ Currently unemployed } & 1.021 & 0.209 & 0.659 & 0.553 \\
\hline & $(1.265)$ & $(1.141)$ & $(1.023)$ & $(0.977)$ \\
\hline \multirow[t]{2}{*}{ Male } & $4.942 * * *$ & $3.974 * * *$ & $2.113 * * *$ & $2.015 * * *$ \\
\hline & $(0.489)$ & $(0.531)$ & $(0.480)$ & $(0.476)$ \\
\hline \multirow[t]{2}{*}{ Age $45-50$ years } & $1.661 * *$ & $1.557 * *$ & 0.584 & 0.579 \\
\hline & $(0.680)$ & $(0.654)$ & $(0.597)$ & $(0.595)$ \\
\hline \multirow[t]{2}{*}{ Age $50-55$ years } & $2.191 * * *$ & $1.775 * * *$ & 0.482 & 0.391 \\
\hline & $(0.704)$ & $(0.686)$ & $(0.641)$ & $(0.637)$ \\
\hline \multirow[t]{2}{*}{ Age $55-60$ years } & $1.789 * * *$ & $1.617 * *$ & -0.720 & -0.886 \\
\hline & $(0.692)$ & $(0.743)$ & $(0.710)$ & $(0.715)$ \\
\hline \multirow[t]{2}{*}{ Age over 60 years } & -1.094 & -1.220 & $-3.583 * * *$ & $-3.623 * * *$ \\
\hline & $(0.984)$ & $(1.045)$ & $(0.970)$ & $(0.968)$ \\
\hline \multirow[t]{2}{*}{ No. times eating veg. / week } & & -0.155 & -0.166 & -0.148 \\
\hline & & $(0.145)$ & $(0.134)$ & $(0.135)$ \\
\hline \multirow[t]{2}{*}{ No. times eating fruit / week } & & 0.156 & 0.097 & 0.122 \\
\hline & & $(0.131)$ & $(0.121)$ & $(0.120)$ \\
\hline \multirow[t]{2}{*}{ No. times drinking alc. / week } & & $0.481 * *$ & $0.414 * *$ & $0.498 * *$ \\
\hline & & $(0.219)$ & $(0.204)$ & $(0.208)$ \\
\hline \multirow[t]{2}{*}{ Alc. drinks / times drinking } & & $0.322 * * *$ & $0.282 * * *$ & $0.297 * * *$ \\
\hline & & $(0.096)$ & $(0.091)$ & $(0.090)$ \\
\hline \multirow[t]{2}{*}{ Times exercise /week } & & 0.114 & 0.083 & 0.078 \\
\hline & & $(0.125)$ & $(0.118)$ & $(0.119)$ \\
\hline \multirow[t]{2}{*}{ Family size } & & -0.102 & -0.096 & -0.139 \\
\hline & & $(0.208)$ & $(0.197)$ & $(0.196)$ \\
\hline \multirow[t]{2}{*}{ Married or cohabiting } & & -0.702 & -0.124 & -0.252 \\
\hline & & $(0.877)$ & $(0.809)$ & $(0.821)$ \\
\hline \multirow[t]{2}{*}{ Divorced } & & -0.734 & -0.303 & -0.373 \\
\hline & & $(1.059)$ & $(1.000)$ & $(1.002)$ \\
\hline \multirow[t]{2}{*}{ Number of cigarettes / week } & & 0.033 & $0.065 * *$ & $0.056^{*}$ \\
\hline & & $(0.030)$ & $(0.029)$ & $(0.029)$ \\
\hline \multirow[t]{2}{*}{ BMI $\left(\mathrm{kg} / \mathrm{m}^{2}\right)$} & & $0.605 * * *$ & $0.398 * * *$ & $0.397 * * *$ \\
\hline & & $(0.052)$ & $(0.053)$ & $(0.053)$ \\
\hline \multirow[t]{2}{*}{ Upper secondary education } & & -0.061 & 0.368 & 0.490 \\
\hline & & $(1.375)$ & $(1.281)$ & $(1.267)$ \\
\hline \multirow[t]{2}{*}{ Post-secondary non-tertiary education } & & 1.259 & 1.335 & 1.371 \\
\hline & & $(1.214)$ & $(1.076)$ & $(1.077)$ \\
\hline \multirow[t]{2}{*}{ Bachelor or equivalent level } & & 0.780 & 1.201 & 1.316 \\
\hline & & $(1.210)$ & $(1.043)$ & $(1.040)$ \\
\hline \multirow[t]{2}{*}{ Master or equivalent level } & & -0.626 & 0.273 & 0.477 \\
\hline & & $(1.337)$ & $(1.167)$ & $(1.159)$ \\
\hline \multirow[t]{2}{*}{ Doctoral or equivalent level } & & 0.092 & 0.988 & 0.926 \\
\hline & & $(1.519)$ & $(1.306)$ & $(1.294)$ \\
\hline Diastolic 2000 & & & $0.336 * * *$ & $0.346^{* * *}$ \\
\hline & & & $(0.023)$ & $(0.023)$ \\
\hline Constant & $78.988 * * *$ & $61.620 * * *$ & $41.972 * * *$ & $40.430 * * *$ \\
\hline & $(0.495)$ & $(2.165)$ & $(2.205)$ & $(2.274)$ \\
\hline R-squared & 0.069 & 0.162 & 0.271 & 0.279 \\
\hline $\mathrm{N}$ & 1675 & 1675 & 1656 & 1656 \\
\hline
\end{tabular}

Note: The dependent variable is diastolic blood pressure.

The reference category for the age dummies is being 41-44 years old in 2000 .

The reference category for the Male dummy is female.

The reference category for the age dummies is 41-44 years old. The reference category for the married or cohabiting dummy is not being married or cohabiting. The reference category for the divorced dummy is not divorced The reference category for the educational dummies is lower secondary education or less.

Statistical significance: $* \mathrm{p}<0.1, * * \mathrm{p}<0.05, * * * \mathrm{p}<0.01$ 
Table A3: The effect of unemployment on systolic blood pressure

\begin{tabular}{|c|c|c|c|c|}
\hline Months of unemployment & $\begin{array}{l}-0.026 \\
(0.095)\end{array}$ & $\begin{array}{l}-0.017 \\
(0.101)\end{array}$ & $\begin{array}{l}-0.009 \\
(0.084)\end{array}$ & $\begin{array}{l}-0.027 \\
(0.084)\end{array}$ \\
\hline \multirow[t]{2}{*}{ Currently unemployed } & 0.288 & -0.759 & -0.121 & -0.299 \\
\hline & $(1.874)$ & $(1.862)$ & $(1.520)$ & $(1.472)$ \\
\hline \multirow[t]{2}{*}{ Male } & $4.349 * * *$ & $2.740 * * *$ & -0.865 & -0.922 \\
\hline & $(0.850)$ & $(0.885)$ & $(0.719)$ & $(0.714)$ \\
\hline \multirow[t]{2}{*}{ Age $45-50$ years } & $2.798 * * *$ & $2.987 * * *$ & $1.501 *$ & $1.481^{*}$ \\
\hline & $(1.008)$ & $(0.978)$ & $(0.814)$ & $(0.815)$ \\
\hline \multirow[t]{2}{*}{ Age 50-55 years } & $5.633 * * *$ & $5.797 * * *$ & $2.743 * * *$ & $2.592 * * *$ \\
\hline & $(1.073)$ & $(1.052)$ & $(0.944)$ & $(0.958)$ \\
\hline \multirow[t]{2}{*}{ Age 55-60 years } & $10.341 * * *$ & $10.664 * * *$ & $4.991 * * *$ & $4.813 * * *$ \\
\hline & $(1.084)$ & $(1.164)$ & $(1.053)$ & $(1.053)$ \\
\hline \multirow{2}{*}{ Age over 60 years } & $11.057 * * *$ & $11.769 * * *$ & $5.415^{* * *}$ & $5.411 * * *$ \\
\hline & $(1.762)$ & $(1.838)$ & $(1.485)$ & $(1.484)$ \\
\hline \multirow[t]{2}{*}{ No. times eating veg. / week } & & 0.008 & 0.118 & 0.162 \\
\hline & & $(0.232)$ & $(0.207)$ & $(0.202)$ \\
\hline \multirow[t]{2}{*}{ No. times eating fruit / week } & & 0.179 & 0.174 & 0.194 \\
\hline & & $(0.218)$ & $(0.174)$ & $(0.173)$ \\
\hline \multirow[t]{2}{*}{ No. times drinking alc. / week } & & $0.675 * *$ & $0.952 * * *$ & $1.070 * * *$ \\
\hline & & $(0.339)$ & $(0.296)$ & $(0.298)$ \\
\hline \multirow[t]{2}{*}{ Alc. drinks / times drinking } & & $0.442 * *$ & $0.393 * * *$ & $0.417 * * *$ \\
\hline & & $(0.185)$ & $(0.149)$ & $(0.148)$ \\
\hline \multirow[t]{2}{*}{ Times exercise /week } & & 0.278 & 0.112 & 0.099 \\
\hline & & $(0.216)$ & $(0.190)$ & $(0.189)$ \\
\hline \multirow[t]{2}{*}{ Family size } & & 0.513 & 0.498 & 0.440 \\
\hline & & $(0.340)$ & $(0.304)$ & $(0.302)$ \\
\hline \multirow[t]{2}{*}{ Married or cohabiting } & & -1.995 & -0.638 & -0.779 \\
\hline & & $(1.365)$ & $(1.130)$ & $(1.131)$ \\
\hline \multirow[t]{2}{*}{ Divorced } & & $-3.638 * *$ & -1.482 & -1.529 \\
\hline & & $(1.613)$ & $(1.376)$ & $(1.382)$ \\
\hline \multirow[t]{2}{*}{ Number of cigarettes / week } & & 0.048 & 0.060 & 0.049 \\
\hline & & $(0.050)$ & $(0.045)$ & $(0.043)$ \\
\hline \multirow[t]{2}{*}{ BMI $(\mathrm{kg} / \mathrm{m} 2)$} & & $0.704 * * *$ & $0.395 * * *$ & $0.407 * * *$ \\
\hline & & $(0.089)$ & $(0.088)$ & $(0.088)$ \\
\hline \multirow[t]{2}{*}{ Upper secondary education } & & -1.909 & -1.590 & -1.450 \\
\hline & & $(2.480)$ & $(2.099)$ & $(2.081)$ \\
\hline \multirow[t]{2}{*}{ Post-secondary non-tertiary education } & & -0.166 & -0.509 & -0.494 \\
\hline & & $(2.051)$ & $(1.643)$ & $(1.644)$ \\
\hline \multirow[t]{2}{*}{ Bachelor or equivalent level } & & -1.628 & -0.595 & -0.485 \\
\hline & & $(2.008)$ & $(1.640)$ & $(1.637)$ \\
\hline \multirow[t]{2}{*}{ Master or equivalent level } & & $-4.553 * *$ & -2.562 & -2.306 \\
\hline & & $(2.140)$ & $(1.744)$ & $(1.765)$ \\
\hline \multirow[t]{2}{*}{ Doctoral or equivalent level } & & $-4.631 *$ & -2.789 & -2.812 \\
\hline & & $(2.450)$ & $(2.055)$ & $(2.048)$ \\
\hline Systolic 2000 & & & $0.523 * * *$ & $0.522 * * *$ \\
\hline & & & $(0.029)$ & $(0.028)$ \\
\hline Constant & $123.722 * * *$ & $103.314 * * *$ & $48.561 * * *$ & $47.200 * * *$ \\
\hline & $(0.789)$ & $(3.940)$ & $(3.713)$ & $(3.822)$ \\
\hline R-squared & 0.076 & 0.135 & 0.335 & 0.340 \\
\hline $\mathrm{N}$ & 1675 & 1675 & 1656 & 1656 \\
\hline
\end{tabular}

Note: The dependent variable is systolic blood pressure.

The reference category for the age dummies is being 41-44 years old in 2000.

The reference category for the Male dummy is female.

The reference category for the age dummies is 41-44 years old. The reference category for the married or cohabiting dummy is not being married or cohabiting. The reference category for the divorced dummy is not divorced 
The reference category for the educational dummies is lower secondary education or less.

Statistical significance: $* \mathrm{p}<0.1, * * \mathrm{p}<0.05, * * * \mathrm{p}<0.01$ 
Table A4: The effect of unemployment on biomarkers

\begin{tabular}{|c|c|c|c|c|}
\hline & $\begin{array}{l}\text { Self- } \\
\text { reported } \\
\text { health }\end{array}$ & Hypertension & $\begin{array}{l}\text { C-reactive } \\
\text { protein }\end{array}$ & Glucose \\
\hline Months of unemployment & $\begin{array}{l}0.010 * * * \\
(0.003)\end{array}$ & $\begin{array}{l}0.003 \\
(0.002)\end{array}$ & $\begin{array}{l}-0.004 \\
(0.006)\end{array}$ & $\begin{array}{l}-0.001 * * * \\
(0.000)\end{array}$ \\
\hline Currently unemployed & $\begin{array}{l}0.257 * * * \\
(0.085)\end{array}$ & $\begin{array}{l}0.011 \\
(0.049)\end{array}$ & $\begin{array}{l}0.070 \\
(0.113)\end{array}$ & $\begin{array}{l}0.021 \\
(0.017)\end{array}$ \\
\hline Male & $\begin{array}{l}-0.027 \\
(0.038)\end{array}$ & $\begin{array}{l}0.081 * * * \\
(0.021)\end{array}$ & $\begin{array}{l}-0.070 \\
(0.046)\end{array}$ & $\begin{array}{l}0.023 * * * \\
(0.009)\end{array}$ \\
\hline Age $45-50$ years & $\begin{array}{l}0.030 \\
(0.044)\end{array}$ & $\begin{array}{l}0.033 \\
(0.024)\end{array}$ & $\begin{array}{l}0.031 \\
(0.070)\end{array}$ & $\begin{array}{l}0.002 \\
(0.007)\end{array}$ \\
\hline Age 50-55 years & $\begin{array}{l}0.110 * * \\
(0.045)\end{array}$ & $\begin{array}{l}0.026 \\
(0.025)\end{array}$ & $\begin{array}{l}0.063 \\
(0.061)\end{array}$ & $\begin{array}{l}0.014 * \\
(0.007)\end{array}$ \\
\hline Age 55-60 years & $\begin{array}{l}0.084 * * \\
(0.043)\end{array}$ & $\begin{array}{l}0.030 \\
(0.026)\end{array}$ & $\begin{array}{l}0.119 * \\
(0.064)\end{array}$ & $\begin{array}{l}0.013 \\
(0.009)\end{array}$ \\
\hline Age over 60 years & $\begin{array}{l}-0.051 \\
(0.062)\end{array}$ & $\begin{array}{l}0.017 \\
(0.036)\end{array}$ & $\begin{array}{l}0.270 * * * \\
(0.086)\end{array}$ & $\begin{array}{l}0.038 * * * \\
(0.011)\end{array}$ \\
\hline Upper secondary education & $\begin{array}{l}-0.133 \\
(0.094)\end{array}$ & $\begin{array}{l}-0.094^{*} \\
(0.056)\end{array}$ & $\begin{array}{l}0.057 \\
(0.143)\end{array}$ & $\begin{array}{l}-0.003 \\
(0.027)\end{array}$ \\
\hline Post-secondary non-tertiary education & $\begin{array}{l}-0.108 \\
(0.070)\end{array}$ & $\begin{array}{l}-0.066 \\
(0.047)\end{array}$ & $\begin{array}{l}0.035 \\
(0.111)\end{array}$ & $\begin{array}{l}-0.033 * \\
(0.018)\end{array}$ \\
\hline Bachelor or equivalent level & $\begin{array}{l}-0.235 * * * \\
(0.069)\end{array}$ & $\begin{array}{l}-0.060 \\
(0.047)\end{array}$ & $\begin{array}{l}-0.015 \\
(0.109)\end{array}$ & $\begin{array}{l}-0.042 * * \\
(0.019)\end{array}$ \\
\hline Master or equivalent level & $\begin{array}{l}-0.268 * * * \\
(0.078)\end{array}$ & $\begin{array}{l}-0.185 * * * \\
(0.057)\end{array}$ & $\begin{array}{l}-0.105 \\
(0.124)\end{array}$ & $\begin{array}{l}-0.051 * * \\
(0.020)\end{array}$ \\
\hline Doctoral or equivalent level & $\begin{array}{l}-0.271 * \\
(0.144)\end{array}$ & $\begin{array}{l}-0.146^{* *} \\
(0.073)\end{array}$ & $\begin{array}{l}-0.289 \\
(0.178)\end{array}$ & $\begin{array}{l}-0.055^{* * * *} \\
(0.021)\end{array}$ \\
\hline (Bad) self-reported health 2000 & $\begin{array}{l}0.351 * * * \\
(0.027)\end{array}$ & & & \\
\hline Hypertension 2000 & & $\begin{array}{l}0.361 * * * \\
(0.022)\end{array}$ & & \\
\hline Log of C-reactive protein $2000(\mathrm{mg} / \mathrm{l})$ & & & $\begin{array}{l}0.158 * * * \\
(0.013)\end{array}$ & \\
\hline Log of Glucose $2000(\mathrm{mmol} / \mathrm{l})$ & & & & $\begin{array}{l}0.554 * * * \\
(0.085)\end{array}$ \\
\hline Constant & $\begin{array}{l}1.210 * * * \\
(0.087)\end{array}$ & $\begin{array}{l}0.386^{* * * *} \\
(0.051)\end{array}$ & $\begin{array}{l}0.225 * \\
(0.115) \\
\end{array}$ & $\begin{array}{l}0.753 * * * \\
(0.139) \\
\end{array}$ \\
\hline $\begin{array}{l}\text { R-squared } \\
\mathrm{N}\end{array}$ & $\begin{array}{l}0.158 \\
1989\end{array}$ & $\begin{array}{l}0.148 \\
1993\end{array}$ & $\begin{array}{l}0.153 \\
1565\end{array}$ & $\begin{array}{l}0.262 \\
1526\end{array}$ \\
\hline
\end{tabular}

Note: The dependent variables are bad self-reported health and biomarkers.

Included in regressions but not reported are five regional dummies.

The reference category for the age dummies is being 41-44 years old in 2000 .

The reference category for the Male dummy is female.

The reference category for the age dummies is $41-44$ years old. The reference category for the married or cohabiting dummy is not being married or cohabiting. The reference category for the divorced dummy is not divorced

The reference category for the educational dummies is lower secondary education or less.

$* \mathrm{p}<0.1, * * \mathrm{p}<0.05, * * * \mathrm{p}<0.01$ 
Table A5: The effect of biomarkers on self-reported health.

\begin{tabular}{lll}
\hline Hypertension 2000 & $0.270^{* * *}$ & $0.171^{* * *}$ \\
Log of C-reactive protein 2000 $(\mathrm{mg} / \mathrm{l})$ & $(0.034)$ & $(0.034)$ \\
& $\left(0.025^{* * *}\right.$ & $0.021^{* * *}$ \\
Glucose 2000 (mmol/l) & $0.629^{* * *}$ & $(0.008)$ \\
& $(0.134)$ & $0.382^{* * *}$ \\
Male & & $(0.133)$ \\
& & 0.046 \\
Age 45-50 years & & $(0.039)$ \\
& & 0.033 \\
Age 50-55 years & & $(0.056)$ \\
& & $0.189^{* * *}$ \\
Age 55-60 years & & $(0.059)$ \\
& & $0.339^{* * *}$ \\
Age over 60 years & & $(0.054)$ \\
& & $0.469^{* * *}$ \\
Constant & & $(0.050)$ \\
& $0.766^{* * *}$ & $0.940^{* * *}$ \\
R-squared & $(0.222)$ & $(0.220)$ \\
$\mathrm{N}$ & 0.039 & 0.076 \\
\hline
\end{tabular}

Notes: The dependent variable is bad self-reported health.

Statistical significance: ${ }^{*} \mathrm{p}<0.1, * * \mathrm{p}<0.05, * * * \mathrm{p}<0.01$ 